\title{
Evaluasi Usabilitas Desain Interface Meja Pelayanan Pengatur Perjalanan Kereta Api Jenis Visual Display Unit (VDU)
}

\author{
Herlina K.Nurtjahyo ${ }^{1}$, Tubagus Raihar Maqdisi², Boy N. Moch ${ }^{3}$ \\ (1) Teknik Industri, Universitas Islam As'Syafiiyah, , ${ }^{(2)}$ Departemen Teknik Industri Universitas Indonesia, \\ ${ }^{(3)}$ Departemen Teknik Industri Universitas Indonesia
}

Email: (1) linanurtjahyo@gmail.com, ${ }^{(2)}$ tubagus.maqdisi@gmail.com, ${ }^{(3)}$ boymoch@eng.ui.ac.id

\begin{abstract}
Abstrak
Tingginya jumlah penumpang membuat PT KAI menambah armada kereta api di Indonesia sehingga meningkatnya kepadatan lalu lintas perkeretaapian. Kepadatan lalu lintas perkeretaapian berpengaruh terhadap pekerjaan pengatur perjalanan kereta api yang menggunakan meja pelayanan sebagai alat utama pelayanan kereta api. Kedepannya meja pelayanan jenis Visual Display Unit akan digunakan untuk menggantikan meja pelayanan yang lama. Penelitian ini bertujuan untuk mengevaluasi apakah interface meja pelayanan jenis Visual Display Unit telah memenuhi standar ergonomi. Kriteria evaluasi yang digunakan pada penelitian ini adalah efectiveness, efficiency, learnability dan juga satisfaction. Adapun metode penelitian yang digunakan adalah Hierarchy Task Analysis, performance measurement, System Usability Scale, USE Questionairre, and Restrospective Think Aloud. Hasil penelitian menghasilkan usulan pengembangan interface meja pelayanan jenis Visual Display Unit untuk memenuhi standarergonomi.
\end{abstract}

Kata Kunci: Ergonomi kognitif, Human Computer Interaction, Usability, Hierarchy Task Analysis, Meja Pelayanan Pengatur Perjalan Kereta Api.

\section{Pendahuluan}

Kereta api merupakan moda transportasi yang efisien untuk mengangkut jumlah penumpang yang tinggi sehingga sangat cocok untuk angkutan massal. Salah satu negara yang sedang memanfaatkan moda transportasi kereta api ini adalah Indonesia. Kereta api di Indonesia diharapkan membawa efisiensi dan efektivitas untuk transportasi maupun sistem logistik nasional. Untuk itu, inovasi dan kualitas pelayanan dalam transportasi terus ditingkatkan untuk mendorong perekonomian Indonesia.

Salah satu sektor yang penting dalam pelayanan kereta api adalah sistem persinyalan kere ta api. Sistem ini mengatur lalu lintas perjalanan kereta api yang berfungsi untuk memastikan kelancaran perjalanan kereta api dan menghindari terjadinya kecelakaan. PT KAI mempunyai petugas khusus yang menangani operasi sistem persinyalan ini, yaitu pengatur perjalanan kereta api. Petugas pengatur perjalanan kereta api adalah orang yang melakukan pengatu ran perjalanan kereta api dalam batas stasiun operasi atau beberapa stasiun operasi dalam wilayah pengaturannya.

Padatnya lalu lintas perjalanan kereta api, dimana penambahan jumlah armada KRL tidak diikuti dengan penambahan jalur rel berakibat keterlambatan dan antrian panjang kereta api. Pada tahun 2014 kereta barang memiliki rata-rata keterlambatan selama 140 menit, sedangkan kereta penumpang memiliki rata-rata keterlambatan 36 menit. Hal ini membuat beban kerja pengatur perjalanan kereta api meningkat. Besarnya beban kerja harus ditunjang dengan peralatan yang memadai. Dalam menunjang pekerjaannya, seorang pengatur perjalanan kereta api menggunakan alat yang disebut meja pelayanan. Meja Pelayanan adalah alat yang digunakan untuk mengubah sinyal maupun wesel yang berada pada jalur kereta api untuk mengatur lalu lintas kereta api. Saat ini kebanyakan meja pelayanan yang digunakan adalah meja pelayanan jenis Local Control Panel. Meja pelayanan jenis Local Control Panel ini sudah digunakan di Indonesia sejak tahun 1990an menggantikan sistem persinyalan mekanik. Namun saat ini sudah ada meja pelayanan berbasis komputer yang umum disebut dengan meja pelayanan jenis visual display unit (VDU). 


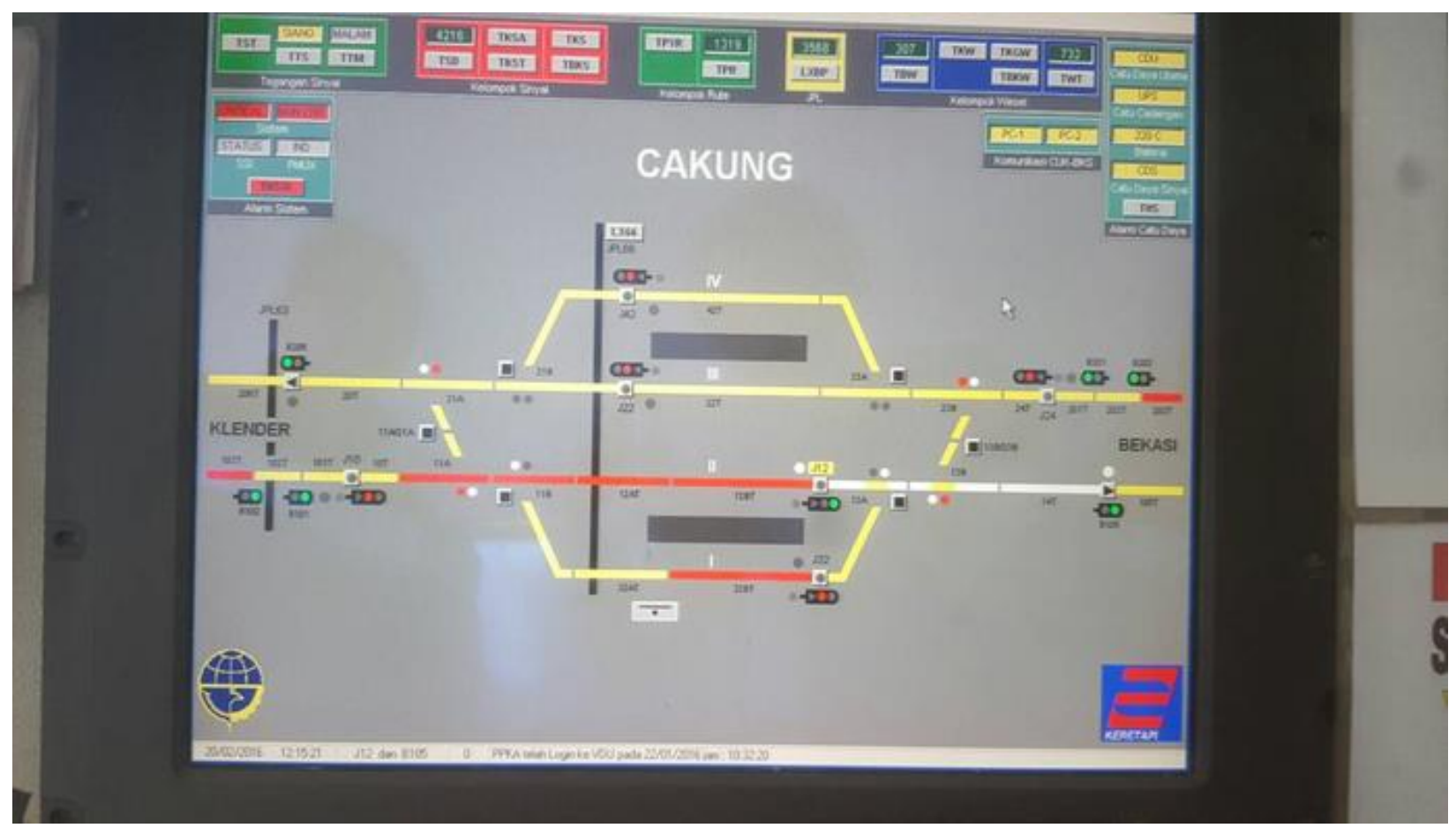

Gambar 1. Interface Meja Pelayanan Jenis VDU

Kedepannya, dikarenakan meja pelayanan yang jenis VDU dinilai lebih efisien secara tempat dan juga kemudahan suku cadang, meja pelayanan jenis VDU ini akan banyak digunakan. Namun dibutuhkan proses adaptasi seorang PPKA dalam mengoperasikan meja pelayanan jenis VDU ini, sehingga perlu diteliti apakah meja pelayanan jenis VDU sudah memenuhi standarergonomi, terutama dari sisi interface.

Interaksi petugas pengatur perjalanan kereta api dengan meja pelayanan ini dapat dikaji berdasarkan bidang ilmu ergonomi kognitif, yaitu Human Computer Interaction. Human Computer Interaction mempelajari apakah suatu sistem layak digunakan untuk menunjang pekerjaan, dimana sistem tersebut harus efektif, efisien dan memberikan kepuasan pagi penggunanya. Selain itu desain interface yang baik harus mudah dipelajari oeleh penggunanya.

Dengan desain interface meja pelayanan yang efisien, efektif, mudah dipelajari, dan memberikan kepuasan, petugas pengatur perjalanan kereta api dapat melaksanakan tugasnya dengan lebih baik, sehingga performa mereka meningkat dalam menghadapi tantangan meningkatnya volume perjalanan kereta api. Dengan demikian, maka kesalahan manusia dapat dihindari sehingga tidak terjadi kecelakaan maupun keterlambatan yang berpengaruh langsung terhadap kualitas pelayanan kereta api.

\section{Studi Literatur}

Pada bagian ini dibahas landasan teori yang dijadikan acuan dalam penelitian ini. Tinjauan teoritis terdiri dari bidang penelitian, objek penelitian, serta metode yang digunakan dalam penelitian ini.

\subsection{Pengatur Perjalanan Kereta Api}

Berdasarkan Peraturan Pemerintah Republik Indonesia Nomor 72 Tahun 2009 Tentang Lalu Lintas Dan Angkutan Kereta Api, petugas pengatur perjalanan kereta api adalah orang yang melakukan pengaturan perjalanan kereta api dalam batas stasiun operasi atau beberapa stasiun operasi dalam wilayah pengaturannya. Petugas pengendali perjalanan kereta api juga melakukan pengendalian perjalanan kereta api dari beberapa stasiun dalam wilayah pengendaliannya.

\subsection{Ergonomi Kognitif}

Ergonomi kognitif adalah cabang ergonomi yang berkaitan dengan proses mental manusia, termasuk di dalamnya persepsi, ingatan, dan reaksi, sebagai akibat dari interaksi manusia terhadap pemakaian elemen sistem. Topik-topik 
yang relevan dalam ergonomi kognitif antara lain adalah beban kerja, pengambilan keputusan, performa, interaksi manusia-komputer, kehandalan manusia, stres kerja dan training. Ergonomi kognitif mempelajari kognisi dalam sistem kerja terutama yang berkaitan dengan setelan operasi, dalam rangka mengoptimalkan kesejahteraan manusia dan performa sistem.

\subsection{Human Computer Interaction}

Interaksi manusia dan komputer (human-computer interaction/HCI) adalah disiplin ilmu yang mempelajari hubungan antara manusia dan komputer yang meliputi perancangan, evaluasi, dan implementasi antarmuka pengguna komputer agar mudah digunakan oleh manusia. Ilmu ini berusaha menemukan cara yang paling efisien untuk merancang pesan elektronik. Sedangkan interaksi manusia dan komputer sendiri adalah serangkaian proses, dialog dan kegiatan yang dilakukan oleh manusia untuk berinteraksi dengan komputer yang keduanya saling memberikan masukan dan umpan balik melalui sebuah antarmuka untuk memperoleh hasil akhir yang diharapkan.

Sebagai bidang penelitian, Interaksi Manusia Komputer terletak di persimpangan antara ilmu komputer, ilmu perilaku (behavioral sciences), desain, studi media, dan beberapa bidang studi lainnya. Istilah ini pertama kali dipopulerkan oleh Stuart K. Card dan Allen Newell dari Carnegie Mellon University dan Thomas P. Moran dari IBM Research tahun 1983 dalam buku mereka, The Psychology of Human Computer Interaction.

\subsection{Usability}

Usability didefinisikan dalam ISO 9241-11 Usability Guide, sebagai tingkat kepuasan pengguna, serta penggunaan yang efektif dan efisien dari suatu produk oleh pengguna tertentu untuk tujuan tertentu (ISO 9241-11, 1998). Dalam rangka mengevaluasi usability, efektivitas produk diukur dengan penggunaan yang tepat untuk tujuan tertentu dan mencapai suatu keutuhan fungsi sistem yang dievaluasi. Di sisi lain, efisiensi dievaluasi oleh pengukuran sumber daya yang dihabiskan dalam mencapai penggunaan yang tepat dan keutuhan. Sementara itu, kepuasan mengacu pada kenyamanan dan nilai estetika dari pengguna.

\subsubsection{Single Ease Question}

Single Ease Question merupakan metode usability yang dilaksanakan setelah performance measurement dimana pengguna diminta untuk menilai seberapa sulit pekerjaan yang telah dilakukan dengan skala likert. Single Ease Question dapat digunakan untuk mengukur tingkat kepuasan tugas dalam suatu proses penilaian usability (Sauro \& Lewis, 2012).

\subsubsection{System Usability Scale}

Kuesioner System Usability Scale diciptakan oleh Brooke (1996) sebagai salah satu alat ukur terhadap persepsi subjektif pengguna suatu produk atau system. SUS paling banyak digunakan karena kemudahan penggunaan, cenderung dapat menekan biaya, dan memiliki tingkat reliabilitas yang tinggi (Bangour, Kortum, dan Miller; 2009)

\subsubsection{USE Questionnaire: Usefulness, Satisfaction, and Fase of use}

Diciptakan oleh Arnie Lund (2001) sebagai pengguna suatu produk untuk melihat aspek Usefulness, Ease of Use, Ease of Learn, dan Satisfaction. Komponen ini diukur berdasarkan skala likert Tujuh poin. USE digunakan dalam penelitian ini untuk menggali lebih jauh kebutuhan akan rekomendasi yang lebih baik, dan menvalidasi hasil SUS.

\subsubsection{Retrospective Think Aloud}

Retrospective Think Aloud merupakan metode usability untuk mengumpulkan pendapat verbal responden setelah selesai melakukan pengukuran performa.

\subsection{Task Analysis}

Task Analysis adalah salah satu metode yang dapat digunakan dalam mengevaluasi desain suatu interface. Menurut (Hackos \& Redish, 1998) Task analysis membantu untuk memahami permasalahan interface antara lain; tujuan yang ingin dicapai pengguna, apa yang dilakukan pengguna untuk mencapai tujuannya, dan alur kerja bagaimana pengguna melakukan tugas.

Salah satu teknik Task Analysis yang sering digunakan adalah Hierarchical Task Analysis. Hierarchy Task Analysis (HTA) merupakan sebuah pendekatan yang dikembangkan untuk mengeksplor Task-Task melalui hirarki dari tujuan yang akan dicapai, dimana HTA pun disertai plans yang menjelaskan mengenai rangkaian pekerjaan yang harus dilakukan untuk mencapai goals dalam kondisi tertentu. (Annett dan Duncan, 1972). HTA telah digunakan untuk 
banyak bidang termasuk dalam evaluasi desain interface, alokasi sumber daya, desain kerja, prediksi error, dan juga pengukuran beban kerja. HTA menggambarkan hirarki pekerjaan atau sub pekerjaan dalam bentuk teks maupun gambar.

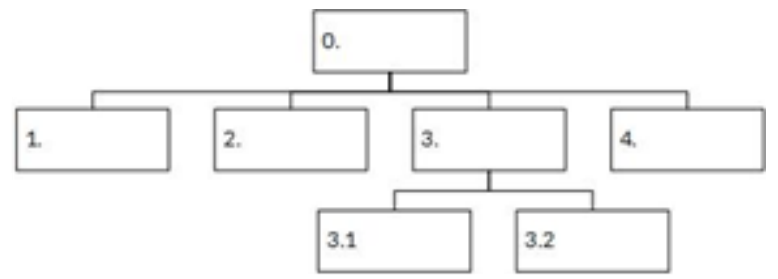

\section{Gambar 2. Contoh Hierarchical Task Analysis}

Ada banyak metode yang dikembangkan dari Hierarchical Task Analysis, salah satunya adalah metode SHERPA. Metode Systematic Human Error Reduction and Prediction Approach (SHERPA) dikenalkan oleh Embrey (1986). SHERPA menggunakan Hierarchical Task Analysis

dengan error taxonomy untuk mengidentifikasi jenis kesalahan mana saja yang dapat terjadi dalam tiap langkah kerja. Tujuan dari penggunaan SHERPA tidak hanya untuk mengidentifikasi error pada desain yang ada, tapi juga sebagaidasar pertimbangan desain di masa depan (Stanton, 2002).

\section{Metode Penelitian}

Pengumpulan data diawali dengan penentuan kriteria yang digunakan untuk mengevaluasi desain interface meja pelayanan. Kemudian, peneliti menentukan responden yang tepat dan merancang tugas yang digunakan.

Tugas yang digunakan dibuat berdasarkan Hierarchical Task Analysis (HTA) dengan Metode Systematic Human Error Reduction and Prediction Approach (SHERPA) dikenalkan oleh Embrey (1986). SHERPA menggunakan Hierarchical Task Analysis dengan error taxonomy untuk mengidentifikasi jenis kesalahan mana saja yang dapat terjadi dalam tiap langkah kerja. Tujuan dari penggunaan SHERPA tidak hanya untuk mengidentifikasi error pada desain yang ada, tapi juga sebagai dasar pertimbangan desain di masa depan (Stanton, 2002).

Setelah itu dilakukan performance measurement dimana pengguna diminta untuk menilai seberapa sulit pekerjaan yang telah dilakukan dengan skala likert, kemudian dilakukan pengisian kuesioner System Usability Scale (SUS) yang diciptakan oleh Brooke (1996) sebagai salah satu alat ukur terhadap persepsi subjektif pengguna suatu produk atau system. SUS paling banyak digunakan karena kemudahan penggunaan, cenderung dapat menekan biaya, dan memiliki tingkat reliabilitas yang tinggi (Bangour, Kortum, dan Miller; 2008).

Selanjutnya dilakukan pengisian kuesioner USE (Usefulness, Satisfaction, and Ease of use) . Diciptakan oleh Arnie Lund (2001) sebagai pengguna suatu produk untuk melihat aspek Usefulness, Ease of Use, Ease of Learn, dan Satisfaction. Komponen ini diukur berdasarkan skala likert Tujuh poin. Setelah itu, dilaksanakan Retrospective Think Aloud yang merupakan metode usability untuk mengumpulkan pendapat verbal responden setelah selesai melakukan pengukuran performa.

Penelitian dilakukan di beberapa stasiun kereta api di Jabodetabek. penelitian ini dilakukan mulai bulan Maret hingga Mei 2016. Penelitian yang dilakukan melibatkan responden yaitu Pengatur Perjalanan Kereta Api (PPKA).

PPKA berusia dalam rentang 22-35 tahun dengan syarat telah mengambil sertifikasi O50, yaitu tanda kecakapan PPKA. Hal ini didasarkan pada anggapan bahwa mereka telah mengerti sistem pelayanan kereta api dan aturanaturan yang ada. Responden yang diteliti harus belum pernah menggunakan meja pelayanan jenis VDU ini sebelumnya, hal ini dimaksudkan agar tidak terjadi bias Jumlah responden adalah 10 orang. Pada penelitian ini tidak dilakukan pengelompokan responden, dimana ke-10 reponden dianggap memiliki karakteristik yang sama. 


\section{Hasil dan Pembahasan}

Pada bagian ini akan dibahas dan dipaparkan mengenai hasil dan pembahasan dari pengolahan data pada penelitian ini.

\subsection{Analisis Kriteria}

Berdasarkan ISO 9241, kriteria usability terbagi menjadi tiga, yaitu: Effectiveness, Efficiency, dan Satisfaction. Efectiveness berdasarkan ISO 9241 adalah keberhasilan pengguna dalam mencapai tujuan. Efisiensi berdasarkan ISO 9241 merupakan sumberdaya yang digunakan dalam menyelesaikan tugas. Sedangkan satisfaction menunjukkan sikap postif kepada penggunaan sistem. Adapun komponen lain yang dijadikan kriteria pada penelitian ini adalah Learnability. Learnability pada ISO 9241-11 didefinisikan sebagai waktu pembelajaran. Learnability merupakan ukuran usability yang dibutuhkan untuk mengetahui bagaimana seseorang menjadi ahli dalam menggunakan produk (Thomas, 2013). Oleh karena itu, peneliti menentukan empat kriteria yang digunakan dalam evaluasi meja pelayanan ini, yaitu: Effectiveness, Efficiency, Learnability dan Satisfaction sebagai berikut:

\begin{tabular}{ll} 
Kriteria & Ukuran \\
\hline Effectivity & $\begin{array}{l}\text { Keberhasilan tugas } \\
\text { Jumlah Error }\end{array}$ \\
\hline Efficiency & Waktu pengerjaan tugas \\
& Jumlah Mouse Click \\
\hline \multirow{2}{*}{ earnability } & $\begin{array}{l}\text { Perbedaan jumlah error per } \\
\text { percobaan } \\
\end{array}$ \\
& Perbedaan waktu pengerjaan tugas \\
& Perbedaan jumlah mouse click \\
\hline Satisfaction & Single Ease Question \\
& System Usability Scale \\
& USE Questionairre \\
\hline
\end{tabular}

Untuk mendapatkan data lebih lanjut untuk rekomendasi maupun perbaikan desain, digunakan metode Hierarchical Task Analysis, SHERPA, dan Retrospective Think Aloud.

Adapun tugas yang dilakukan adalah sebagaiberikut:

Tugas 1: Melayani Kereta Dengan Rute Otomatis

Tugas 2: Menyimpan rute, Melayani Kereta Berhenti Tiba-Tiba dan WeselTerlanggar

Tugas 3: Penghapusan rute dan Melayani dengan kondisi wesel berat

Tugas 4: Melayani Kereta dalam kondisi Rel Gangguan

Tugas 5: Melayani kereta saat ada deteksi gangguan pada rel

Tugas 6: Melayani kereta putar balik arah lokomotif

\subsection{Hierarchical Task Analysis, dan SHERPA}

Tugas-tugas dirancang berdasarkan Hierarchical Task Analysis. Di bawah ini diberikan contoh pembuatan HTA untuk tugas 1:

\subsubsection{HTA Tugas 1}

Tujuan : Melayani penyusulan kereta dengan keadaan rute otomatis 


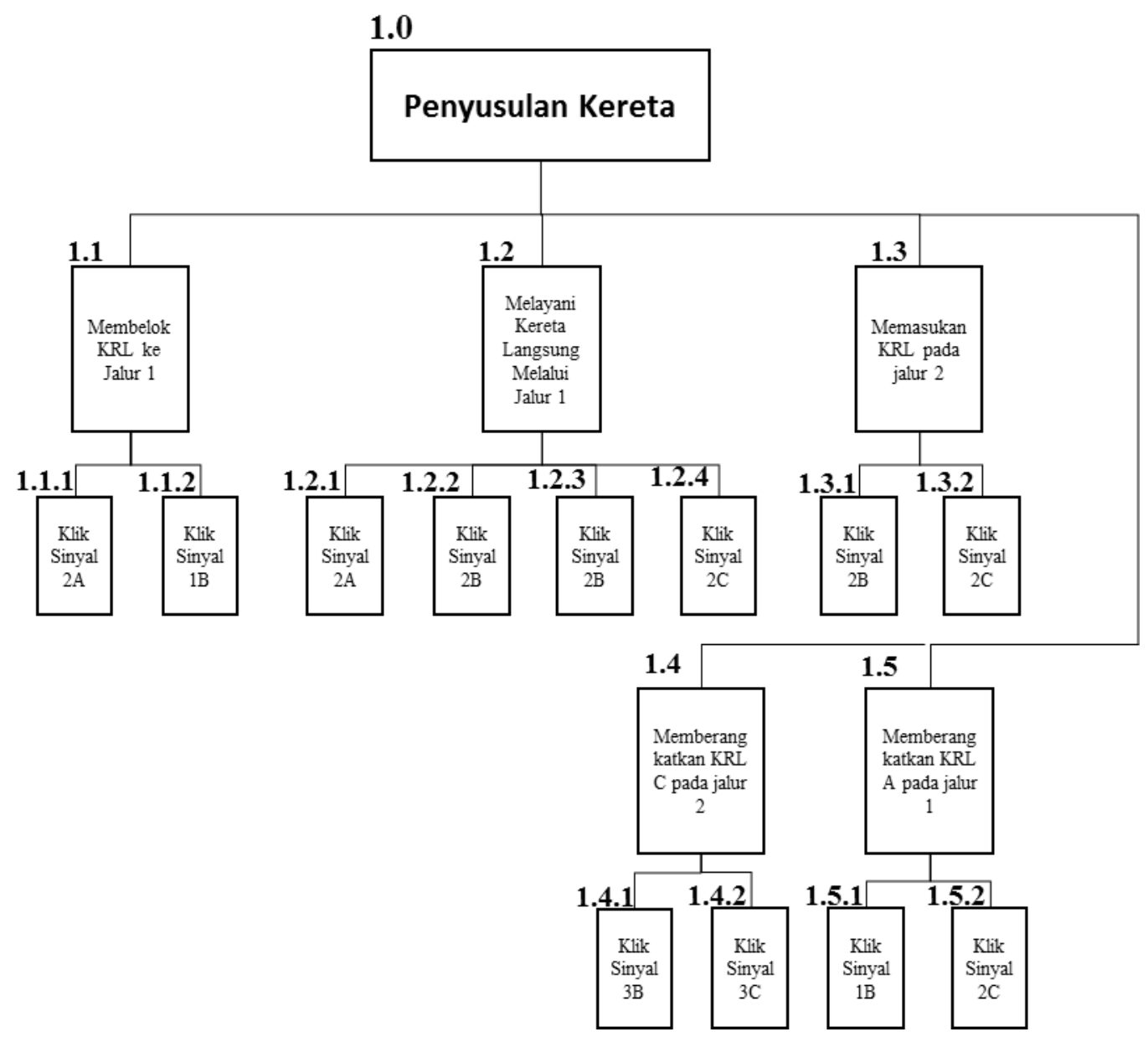

Gambar 3. Hierarchical Task Analysis Untuk Tugas 1

Gambar di atas merupakan Hierarchical Task Analysis untuk tugas 1 di mana terdapat 5 task dengan total tindakan harus dilakukan sebanyak 12 klik.

\subsubsection{Detail Error Tugas 1}

Untuk mengetahui lebih mendalam pada tugas-tugas mana saja responden melakukan kesalahan, peneliti mencatat data kesalahan berdasarkan subtask yang telah dibuat berdasarkan Hierarchical Task Analysis. Berikut merupakan penjelasan kesalahan dari masing-masing tugas, baik dari persentase responden yang melakukan kesalahan maupun detail kesalahan yang terjadi.

Adapun persentase responden yang melakukan kesalahan pada tugas pertama adalah sebagaiberikut: 
Tabel 1. Persentase Responden yang Melakukan Kesalahan pada Tugas 1

\begin{tabular}{clc} 
Langkah & Tugas & $\begin{array}{c}\text { Responden yang } \\
\text { melakukan kesalahan }\end{array}$ \\
\hline $\mathbf{1 . 1}$ & Pembentukan rute Ke Jalur 1 untuk KRL & $30 \%$ \\
\hline $\mathbf{1 . 2}$ & Pembentukan rute ke Jalur 2 untuk Kereta Api & $40 \%$ \\
\hline $\mathbf{1 . 3}$ & Pembentukan rute ke Jalur 3 untuk KRL C & $0 \%$ \\
\hline $\mathbf{1 . 4}$ & Memberangkatkan KRL C di jalur 3 & $0 \%$ \\
\hline $\mathbf{1 . 5}$ & Memberangkatkan KRL A ke st B & $0 \%$ \\
\hline & Tugas 1 & $60 \%$ \\
\hline
\end{tabular}

Dari kesalahan-kesalahan di atas diidentifikasi berdasarkan jenis kesalahan dan jumlah kejadiannya. Tabel di bawah menampilkan kesalahan-kesalahan yang terjadi pada Tugas 1 .

Tabel 2. Kesalahan-kesalahan yang Terjadi pada Tugas 1

\begin{tabular}{|c|c|l|c|c|}
\hline No & Langkah & \multicolumn{1}{|c|}{ Detail Kesalahan } & $\begin{array}{c}\text { Jumlah } \\
\text { Kejadian }\end{array}$ & Tipe Kesalahan \\
\hline 1.1 & $\begin{array}{c}\text { Pembentukan rute Ke } \\
\text { Jalur 1 untuk KRL }\end{array}$ & $\begin{array}{l}\text { Mengklik pada indikator sinyal } \\
\text { dahulu }\end{array}$ & 2 & Kesalahan identifikasi tombol \\
\hline Menan tombol tujuan terlebih & $\begin{array}{c}\text { Kesalahan urutan operasi } \\
\text { Jalur 2 untuk Kereta } \\
\text { Api }\end{array}$ & $\begin{array}{l}\text { Tidak menekan tombol sinyal 2B } \\
\text { dua kali }\end{array}$ & 4 & Kesalahan urutan operasi \\
\hline
\end{tabular}

Pada tahap ini ternyata terjadi kesalahan paling besar di pekerjaan no 1.2, dimana sebanyak 4 responden melakukan kesalahan. Pada Langkah 1.1 terjadi kesalahan dalam mengidentifikasi tombol yang harus diklik, responden mengklik indikator dimana seharusnya mengklik tombol sinyal. Kemudian pada langkah ini juga terjadi kesalahan dalam urutan menekan tombol dimana seharusnya tombol asal terlebih dahulu yang diklik. Terjadi pula kesalahan pada langkah 1.2. Kesalahan yang terjadi adalah sebanyak 4 responden tidak menekan tombol sinyal $2 \mathrm{~B}$ yang seharusnya ditekan sebanyak 2 kali.

Dengan cara yang sama, dilakukan pembuatan HTA untuk tugas 2, 3,4,5, dan tugas 6 .

\subsubsection{SHERPA}

Oleh karena masih terjadi kesalahan dalam pengoperasian meja pelayanan ini, diperlukan analisis tentang kesalahan yang telah terjadi, dan prediksi kesalahan beserta solusinya. Untuk keperluan tersebut, peneliti menggunakan Systematic Human Error Reduction and Prediction Analysis (SHERPA). SHERPA dapat digunakan untuk memprediksi human error yang terjadi pada penggunaan suatu alat.

Tabel 3. Jenis Error Berdasarkan SHERPA

\begin{tabular}{|l|c|l|}
\hline Jenis Error & Kode Failure & \multicolumn{1}{c|}{ Failure Mode } \\
\hline & A1 & Operasi terlalu lama atau terlalu singkat \\
\cline { 2 - 3 } & A2 & Operasi tidak terlaksana sesuaijadwal \\
\cline { 2 - 3 } Action Error & A3 & Operasi dilaksanakan dengan jalan yang tidak tepat \\
\cline { 2 - 3 } & A4 & Operasi terlalu sedikit atau terlalu banyak \\
\cline { 2 - 3 } & A5 & Operasi tidak sejalan \\
\cline { 2 - 3 } & A6 & Operasi yang benar pada objek yang salah \\
\hline
\end{tabular}




\begin{tabular}{|l|c|l|}
\hline Jenis Error & Kode Failure & \multicolumn{1}{|c|}{ Failure Mode } \\
\hline \multirow{3}{*}{} & A7 & Pperasi yang salah pada objek yang benar \\
\cline { 2 - 3 } & A8 & Pekerjaan terlalaikan \\
\cline { 2 - 3 } & A9 & Pekerjaan tidak selesai \\
\cline { 2 - 3 } & A10 & Pekerjaan yag salah pada objek yang salah \\
\hline
\end{tabular}

Pada penggunaan meja pelayanan ini, semua operasi berada pada jenis action. Analisa error yang mungkin terjadi berdas arkan metode SHERPA tertera pada tabel berikut ini:

Tabel 4 Analisis SHERPA untuk Tugas 1

\begin{tabular}{|c|c|c|c|c|c|c|}
\hline Tugas & Deskripsi Tugas & $\begin{array}{l}\text { Mode } \\
\text { Error }\end{array}$ & Deskripsi Error & Konsekuensi & $\begin{array}{l}\text { Tingkat } \\
\text { Kritis }\end{array}$ & Solusi \\
\hline \multirow{3}{*}{$\begin{array}{l}1.1 \\
1.3\end{array}$} & \multirow{3}{*}{ Memasukan KRL } & A3 & $\begin{array}{l}\text { Salah urutan } \\
\text { tombol }\end{array}$ & $\begin{array}{l}\text { Tidak terbentuk } \\
\text { rute }\end{array}$ & Rendah & $\begin{array}{l}\text { Penjelasan tertulis tentang } \\
\text { proseduralat }\end{array}$ \\
\hline & & A6 & $\begin{array}{l}\text { Salah } \\
\text { mengidentifika } \\
\text { si tombol sinyal }\end{array}$ & $\begin{array}{l}\text { Tidak terbentuk } \\
\text { rute }\end{array}$ & Rendah & $\begin{array}{l}\text { Tombol sinyal dibuat } \\
\text { berbeda bentuk dengan } \\
\text { tombol lainnya }\end{array}$ \\
\hline & & A7 & Salah merute & $\begin{array}{l}\text { Kereta berada } \\
\text { pada jalur yang } \\
\text { salah }\end{array}$ & Rendah & $\begin{array}{l}\text { Training, Menggunakan } \\
\text { tombol penghapus rute }\end{array}$ \\
\hline \multirow[b]{2}{*}{1.2} & \multirow{2}{*}{$\begin{array}{l}\text { Melayani kereta } \\
\text { langsung }\end{array}$} & A3 & $\begin{array}{l}\text { Salah urutan } \\
\text { tombol }\end{array}$ & $\begin{array}{l}\text { Tidak terbentuk } \\
\text { rute }\end{array}$ & Rendah & $\begin{array}{l}\text { Penjelasan tertulis tentang } \\
\text { proseduralat }\end{array}$ \\
\hline & & A6 & $\begin{array}{l}\text { Salah } \\
\text { mengidentifika } \\
\text { si tombol sinyal }\end{array}$ & $\begin{array}{l}\text { Tidak terbentuk } \\
\text { rute }\end{array}$ & Rendah & $\begin{array}{l}\text { Tombol sinyal dibuat } \\
\text { berbeda bentuk dengan } \\
\text { tombol lainnya }\end{array}$ \\
\hline \multirow{2}{*}{$\begin{array}{l}1.4 \\
1.5\end{array}$} & \multirow{2}{*}{$\begin{array}{l}\text { Memberangkatkan } \\
\text { KRL }\end{array}$} & A3 & $\begin{array}{l}\text { Salah urutan } \\
\text { tombol }\end{array}$ & $\begin{array}{l}\text { Tidak terbentuk } \\
\text { rute }\end{array}$ & Rendah & $\begin{array}{l}\text { Penjelasan tertulis tentang } \\
\text { proseduralat }\end{array}$ \\
\hline & & A6 & $\begin{array}{l}\text { Salah } \\
\text { mengidentifika } \\
\text { si tombol sinyal }\end{array}$ & $\begin{array}{l}\text { Tidak terbentuk } \\
\text { rute }\end{array}$ & Rendah & $\begin{array}{l}\text { Tombol sinyal dibuat } \\
\text { berbeda bentuk dengan } \\
\text { tombol lainnya }\end{array}$ \\
\hline
\end{tabular}

Tabel di atas menunjukan jenis error, deskripsi, konsekuensi, tingkat kritis, maupun solusi atas kesalahan yang terjadi pada tugas 1. Dengan cara yang sama, dilakukan pembuatan SHERPA untuktugas 2, 3,4,5, dan tugas 6 .

Setelah membuat Hierarchical Task Analysis dan menggunakan SHERPA untuk memprediksi kesalahan, maka didapatkan bahwa kesalahan yang dapat terjadi adalah kesalahan action berupa tidak melaksanakan tugas dengan jalan yang tepat Kesalahan dengan kode A6 juga mungkin terjadi, yaitu operasi yang tepat pada objek yang tidak tepat kesalahan dengan kode A7, yaitu kesalahan operasi yang tidak tepat pada objek yang tepat. 


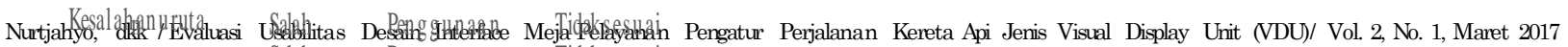

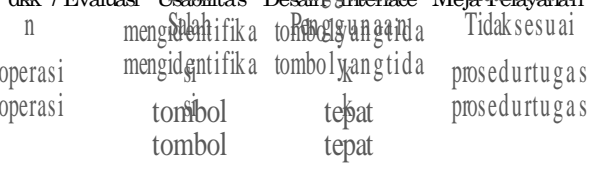

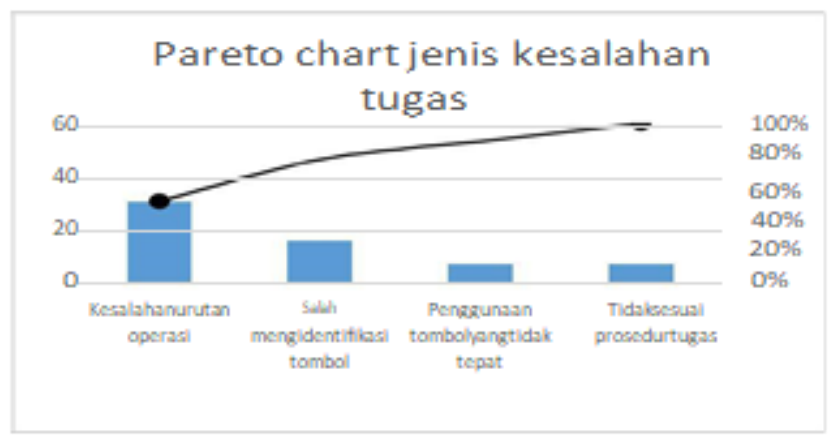

Gambar 4. Diagram Pareto Jenis Kesalahan Tugas

Dari hasil analisis metode SHERPA maupun observasi kesalahan ini didapatkan beberapa solusi untuk mengurangi error antara lain: Membuat prosedur tertulis tentang penggunaan alat, hal ini dimaksudkan agar pengguna mengetahui bagaimana urutan pengerjaan tugas yang benar. Membuat perbedaan antar tombol yang kontras atau pemberian label pada tombol, hal ini dilakukan untuk menghindari kesalahan pengguna dalam mengklik tombol yang dimaksud. Melakukan pelatihan intensif terhadap tindakan yang harus dilakukan terhadap berbagai kondisi.

\subsection{Effectiveness}

Salah satu ukuran effectiveness didapat dengan membagikan jumlah tugas yang berhasil dilaksanakan, dibagikan dengan total tugas yang telah dijalankan dikalikan dengan seratus persen.Ternyata setelah dilakukan pengukuran performa, seluruh responden berhasil melaksanakan ke 6 Task yang telah dilaksanakan. Hal ini disebabkan karena sesungguhnya responden sudah familiar dengan situasi, dan fungsi-fungsi yang ada pada meja pelayanan jenis Visual Display Unit ini karena dibuat serupa dengan meja pelayanan jenis Local Control Panel yang biasa mereka gunakan. Responden pun sudah dinyatakan kompeten karena mereka telah mengambil sertifikasi O-50 dimana sertifikasi itu menandakan kecakapan petugas dalam melayani perjalanan kereta api.

Tabel 5. Tingkat Keberhasilan Tugas pada Performance Measurement

\begin{tabular}{llcccccc} 
No & Responden & Task & Task & Task & Task & Task & Task \\
& & 1 & 2 & 3 & 4 & 5 & 6 \\
\hline 1 & PPKA01 & 1 & 1 & 1 & 1 & 1 & 1 \\
2 & PPKA02 & 1 & 1 & 1 & 1 & 1 & 1 \\
3 & PPKA03 & 1 & 1 & 1 & 1 & 1 & 1 \\
4 & PPKA04 & 1 & 1 & 1 & 1 & 1 & 1 \\
5 & PPKA05 & 1 & 1 & 1 & 1 & 1 & 1 \\
6 & PPKA06 & 1 & 1 & 1 & 1 & 1 & 1 \\
7 & PPKA07 & 1 & 1 & 1 & 1 & 1 & 1 \\
8 & PPKA08 & 1 & 1 & 1 & 1 & 1 & 1 \\
9 & PPKA09 & 1 & 1 & 1 & 1 & 1 & 1 \\
10 & PPKA10 & 1 & 1 & 1 & 1 & 1 & 1 \\
\hline Rata-rata & 1 & 1 & 1 & 1 & 1 & 1
\end{tabular}

Namun, masih terjadi beberapa error yang tidak berpengaruh terhadap keberhasilan tugas. 
Tabel 6. Jumlah Error pada Performance Measurement

\begin{tabular}{cccccccc} 
& & \multicolumn{7}{c}{ Number of Error } \\
Responden & Task & Task & Task & Task & Task & Task & Total \\
& 1 & 2 & 3 & 4 & 5 & 6 & \\
& & & & & & & \\
\hline PPKA 01 & 1 & 0 & 0 & 0 & 1 & 1 & 3 \\
PPKA 02 & 1 & 1 & 0 & 0 & 0 & 1 & 3 \\
PPKA 03 & 1 & 2 & 2 & 0 & 1 & 3 & 9 \\
PPKA 04 & 0 & 1 & 1 & 0 & 0 & 0 & 2 \\
PPKA 05 & 0 & 2 & 1 & 0 & 0 & 0 & 3 \\
PPKA 06 & 0 & 0 & 0 & 0 & 0 & 0 & 0 \\
PPKA 07 & 2 & 3 & 2 & 0 & 0 & 1 & 8 \\
PPKA 08 & 4 & 5 & 3 & 1 & 1 & 6 & 20 \\
PPKA 09 & 0 & 2 & 0 & 0 & 1 & 3 & 6 \\
PPKA 10 & 1 & 3 & 1 & 0 & 0 & 3 & 8 \\
\hline Rata-rata & 1,0 & 1,9 & 1,0 & 0,1 & 0,4 & 1,8 & 6,2 \\
\hline
\end{tabular}

Jumlah error jumlah per Task adalah 1.03 error per subTask dan 0,137 error per subTask dimana jenis-jenis kesalahan dari pengerjaan tugas ini telah diterangkan sebelumnya. Adapun beberapa usulan untuk mengurangi jumlah error ini telah disampaikan pada bagian sebelumnya.

\subsection{Efficiency}

Efisiensi dapat diukur berdasarkan waktu yang dibutuhkan dan usaha yang dikeluarkan. Waktu yang dibutuhkan dapat diukur menggunakan waktu pengerjaan tugas yang telah dilaksanakan oleh responden, adapun usaha yang dikeluarkan dapat diukur dari jumlah klik mouse yang dilakukan oleh petugas PPKA dalam mengoperasikan meja pelayanan.

Tabel 7. Waktu Pengerjaan Tugas pada Performance Measurement

\begin{tabular}{cccccccc} 
Responden & Task & Task & Task & Task & Task & Task & Total \\
& 1 & 2 & 3 & 4 & 5 & 6 & \\
& & & & & & & \\
\hline PPKA01 & 113 & 108 & 116 & 82 & 67 & 199 & 685 \\
PPKA02 & 139 & 181 & 200 & 81 & 32 & 232 & 865 \\
PPKA03 & 108 & 120 & 106 & 44 & 29 & 211 & 618 \\
PPKA04 & 97 & 159 & 73 & 48 & 38 & 134 & 549 \\
PPKA05 & 109 & 146 & 165 & 76 & 51 & 174 & 721 \\
PPKA06 & 141 & 180 & 109 & 65 & 31 & 152 & 678 \\
PPKA07 & 140 & 183 & 112 & 60 & 27 & 222 & 744 \\
PPKA08 & 118 & 164 & 82 & 48 & 38 & 166 & 616 \\
PPKA09 & 94 & 161 & 125 & 52 & 40 & 226 & 698 \\
PPKA10 & 123 & 148 & 132 & 78 & 56 & 176 & 713 \\
\hline
\end{tabular}

Berdasarkan hasil penelitian, dalam satu menit pengerjaan, rata-rata responden berhasil mengerjakan 3,92 subTask. Hal ini dinilai cukup efisien untuk sebuah meja pelayanan. Pada kondisi pelayanan kereta api yang 
sesungguhnya, frekuensi pelayanan kereta pada stasiun yang cukup padat adalah tiap 3 menit, sehingga waktu tersebut dinilai sudah sangat cukup untuk pelayanan kereta.

Komponen kedua yang dijadikan ukuran efisiensi adalah jumlah mouse click.

Tabel 8. Jumlah Mouse Click pada Performance Measurement

Number of Mouse Click

\begin{tabular}{cccccccc} 
Respondens & Task & Task & Task & Task & Task & Task & Total \\
& 1 & 2 & 3 & 4 & 5 & 6 & \\
\hline PPKA01 & 15 & 19 & 20 & 12 & 8 & 34 & 108 \\
PPKA02 & 16 & 23 & 20 & 12 & 6 & 35 & 112 \\
PPKA03 & 14 & 23 & 26 & 12 & 9 & 38 & 122 \\
PPKA04 & 15 & 22 & 22 & 12 & 6 & 31 & 108 \\
PPKA05 & 12 & 26 & 22 & 13 & 6 & 30 & 109 \\
PPKA06 & 12 & 21 & 20 & 12 & 6 & 32 & 103 \\
PPKA07 & 14 & 33 & 25 & 14 & 6 & 35 & 127 \\
PPKA08 & 22 & 32 & 27 & 15 & 8 & 45 & 149 \\
PPKA09 & 12 & 24 & 22 & 13 & 8 & 38 & 117 \\
PPKA10 & 16 & 22 & 23 & 12 & 8 & 36 & 117 \\
\hline Rata-rata & 14,8 & 24,5 & 22,7 & 12,7 & 7,1 & 35,4 & 117,2 \\
\hline
\end{tabular}

Jumlah mouse click untuk pengerjaan pertama kalinya adalah 2,604 click per subTask. Jika dibandingkan dengan meja pelayanan jenis LCP yang biasa digunakan oleh responden penelitian kami, angka ini belum cukup efisien, sebab pada meja pelayanan LCP seluruh subTask dapat dilakukan dengan hanya 1 langkah. Hal ini mungkin bisa diatasi dengan penerapan shortcut keys menggunakan keyboard untuk tombol-tombol tertentu, sehingga bisa menghemat dari segijumlah langkah pengerjaan yang harus dilakukan.

\subsection{Learnability}

Learnability diteliti berdasarkan hasil uji paired t-test untuk mengetahui apakah ada performa responden pada percobaan pertama dan percobaan kedua.

perbedaan signifikan

Tabel 9. Jumlah Error pada Percobaan Kedua

\begin{tabular}{cccccccc} 
& \multicolumn{7}{c}{ Number of Error 2nd } \\
& \multicolumn{7}{c}{ trial } \\
\cline { 2 - 8 } Responden & Task & Task & Task & Task & Task & Task & Total \\
& 1 & 2 & 3 & 4 & 5 & 6 & Error \\
\hline PPKA01 & 0 & 0 & 0 & 0 & 0 & 1 & 1 \\
PPKA02 & 0 & 0 & 0 & 0 & 0 & 1 & 1 \\
PPKA03 & 0 & 2 & 0 & 0 & 0 & 1 & 3 \\
PPKA04 & 0 & 0 & 0 & 0 & 0 & 0 & 0 \\
PPKA05 & 0 & 1 & 2 & 0 & 0 & 0 & 3 \\
PPKA06 & 0 & 0 & 0 & 0 & 0 & 0 & 0 \\
PPKA07 & 1 & 2 & 0 & 0 & 1 & 2 & 6 \\
PPKA08 & 0 & 0 & 1 & 0 & 1 & 2 & 4 \\
PPKA09 & 0 & 0 & 0 & 0 & 0 & 0 & 0 \\
PPKA10 & 0 & 1 & 0 & 0 & 0 & 2 & 3 \\
\hline Rata-rata & 0,1 & 0,6 & 0,3 & 0 & 0,2 & 0,9 & 2,1 \\
\hline
\end{tabular}

Tabel 9 menunjukan jumlah error yang terjadi pada performance measurement yang kedua. 
Tabel 10. Waktu Pengerjaan Tugas pada Percobaan Kedua

\begin{tabular}{|c|c|c|c|c|c|c|c|}
\hline \multirow[b]{2}{*}{ Responden } & & Task & Time & 2nd & trial & & \\
\hline & $\begin{array}{c}\text { Task } \\
1\end{array}$ & $\begin{array}{c}\text { Task } \\
2\end{array}$ & $\begin{array}{c}\text { Task } \\
3\end{array}$ & $\begin{array}{c}\text { Task } \\
4\end{array}$ & $\begin{array}{c}\text { Task } \\
5\end{array}$ & $\begin{array}{c}\text { Task } \\
6\end{array}$ & $\begin{array}{l}\text { Total } \\
\text { Time }\end{array}$ \\
\hline PPKA01 & 94 & 105 & 95 & 45 & $\overline{48}$ & 158 & 545 \\
\hline PPKA02 & 122 & 140 & 102 & 42 & 40 & 188 & 634 \\
\hline PPKA03 & 93 & 110 & 76 & 39 & 26 & 121 & 465 \\
\hline PPKA04 & 106 & 115 & 66 & 33 & 33 & 154 & 507 \\
\hline PPKA05 & 84 & 112 & 122 & 55 & 40 & 130 & 543 \\
\hline PPKA06 & 97 & 103 & 98 & 31 & 37 & 174 & 540 \\
\hline PPKA07 & 120 & 132 & 78 & 42 & 42 & 135 & 549 \\
\hline PPKA08 & 98 & 142 & 87 & 46 & 56 & 161 & 590 \\
\hline РРКА09 & 93 & 123 & 101 & 48 & 53 & 143 & 561 \\
\hline PPKA10 & 81 & 112 & 121 & 47 & 36 & 134 & 531 \\
\hline Rata-rata & 98,8 & 119,4 & 94,6 & 42,8 & 41,1 & 149,8 & 546,5 \\
\hline
\end{tabular}

Tabel 10 menunjukkan waktu pengerjaan tugas pada performance measurement yang kedua.

Tabel 11. Jumlah Mouse Click pada Percobaan Kedua

Number of Mouse Click

2nd Trial

\begin{tabular}{|c|c|c|c|c|c|c|c|}
\hline \multirow[t]{2}{*}{ Responden } & Task & Task & Task & Task & Task & Task & $\begin{array}{c}\text { Total } \\
\text { Mouse }\end{array}$ \\
\hline & 1 & 2 & 3 & 4 & 5 & 6 & Click \\
\hline PPKA01 & 13 & 19 & 20 & 12 & 6 & 36 & 106 \\
\hline PPKA02 & 12 & 19 & 21 & 12 & 6 & 30 & 100 \\
\hline PPKA03 & 12 & 21 & 20 & 12 & 6 & 31 & 102 \\
\hline PPKA04 & 15 & 19 & 20 & 12 & 6 & 31 & 103 \\
\hline PPKA05 & 12 & 19 & 23 & 12 & 6 & 30 & 102 \\
\hline PPKA06 & 12 & 19 & 20 & 12 & 6 & 30 & 99 \\
\hline PPKA07 & 14 & 23 & 20 & 12 & 8 & 32 & 109 \\
\hline PPKA08 & 12 & 19 & 22 & 12 & 9 & 36 & 110 \\
\hline PPKA09 & 12 & 19 & 20 & 12 & 6 & 30 & 99 \\
\hline PPKA 10 & 16 & 22 & 20 & 12 & 6 & 32 & 108 \\
\hline Rata-rata & 13 & 19,9 & 20,6 & 12 & 6,5 & 31,8 & 103,8 \\
\hline
\end{tabular}

Tabel 11 menunjukan jumlah mouse click yang terjadi pada performance measurement yang kedua.

Kemudian dilakukan uji paired t-test untuk mengetahui apakah ada perbedaan signifikan performa responden pada percobaan pertama dan percobaan kedua. 
Tabel 12. Hasil paired t-test untuk tiga Kriteria Learnability

\begin{tabular}{|c|c|c|c|c|}
\hline \multirow[t]{2}{*}{ No } & \multirow[t]{2}{*}{ Responden } & Perbedaan & $P-$ & \multirow[t]{2}{*}{$\begin{array}{l}\text { Kesimpula } \\
\mathrm{n}\end{array}$} \\
\hline & & Rata-rata & Value & \\
\hline 1 & $\begin{array}{l}\text { Jumlah } \\
\text { Error } \\
\text { Total } \\
\text { Waktu }\end{array}$ & 4,1 error & 0,023 & Signifikan \\
\hline 2 & $\begin{array}{l}\text { Pengerjaan } \\
\text { Tugas } \\
\text { Jumlah }\end{array}$ & $\begin{array}{l}142,2 \\
\text { detik }\end{array}$ & 0,0000 & Signifikan \\
\hline 3 & $\begin{array}{l}\text { Mouse } \\
\text { Click }\end{array}$ & 13,4 klik & 0,004 & Signifikan \\
\hline
\end{tabular}

Perbedaan dikatakan signifikan apabila P-Value < 0,05. Secara umum dari total keseluruhan 6 tugas yang telah dikerjakan selama dua kali terdapat perbedaan signifikan baik dari segi kesalahan, waktu, maupun jumlah usaha yang dikeluarkan. Dari segi kesalahan, perbedaan rata-rata percobaan pertama dan kedua mencapai 4,1 error. Kemudian dari segi total waktu pengerjaan, rata-rata percobaan kedua lebih cepat 142,2 detik dibandingkan percobaan pertama, begitu pula untuk rata-rata jumlah klik percobaan kedua yang lebih rendah 13,4 klik dibandingkan percobaan pertama. Hal ini menandakan bahwa responden sudah dapat

dengan cepat mempelajari cara menggunakan meja pelayanan ini.

\subsection{Satisfaction}

Alat ukur yang digunakan dalam pengukuran kriteria satisfaction adalah Single Ease Question, System Usability Scale, dan juga USE Questionairre.

Single Ease Question digunakan untuk mengukur Task level satisfaction. Setelah selesai melaksanakan Task, responden diminta untuk memberikan peringkat seberapa sulit pekerjaan yang telah dilaksanakan.

Tabel 13. Hasil Penilaian Single Ease Question

\begin{tabular}{|c|c|c|c|c|c|c|c|}
\hline & & & \multicolumn{5}{|c|}{ Kesulitan } \\
\hline & Task & Task & Task & Task & Task & Task & Rata- \\
\hline \multicolumn{8}{|l|}{ Responden } \\
\hline & & & & & & & rata \\
\hline & 1 & 2 & 3 & 4 & 5 & 6 & \\
\hline & & & & & & & SEQ \\
\hline PPKA 1 & 2 & 2 & 3 & 3 & 3 & 4 & 2,83 \\
\hline PPKA 2 & 2 & 3 & 4 & 3 & 2 & 2 & 2,67 \\
\hline PPKA 3 & 1 & 2 & 3 & 1 & 2 & 3 & 2,00 \\
\hline PPKA 4 & 1 & 1 & 2 & 2 & 2 & 2 & 1,67 \\
\hline PPKA 5 & 1 & 1 & 2 & 1 & 1 & 3 & 1,50 \\
\hline PPKA 6 & 1 & 1 & 5 & 5 & 5 & 3 & 3,33 \\
\hline PPKA 7 & 1 & 1 & 1 & 1 & 1 & 2 & 1,17 \\
\hline PPKA 8 & 1 & 1 & 3 & 2 & 1 & 4 & 2,00 \\
\hline PPKA 9 & 1 & 2 & 3 & 3 & 4 & 5 & 3,00 \\
\hline PPKA 10 & 1 & 5 & 3 & 2 & 2 & 2 & 2,50 \\
\hline Rata-rata & 1,2 & 1,9 & 2,9 & 2,3 & 2,3 & 3 & 2,27 \\
\hline
\end{tabular}

Dari ke 6 Task yang telah dilaksanakan, responden menilai bahwa tugas yang paling sulit adalah tugas 6, dengan nilai 3 dari skala 7, diikuti dengan tugas 3 dengan nilai 2,9. Rata-rata kesulitan dari ke-6 tugas adalah 2,27 dari skala 7. Hal ini menunjukkan dalam menggunakan meja pelayanan jenis VDU, tugas yang diminta tidak memiliki tingkat kesulitan yang berarti 


\subsubsection{System Usability Scale}

Suatu sistem dikatakan usable apabila memiliki skor di atas 70, di bawah itu skor 50-70 dianggap marginal, sedangkan skor di bawah 50 dianggap buruk. Berdasarkan hasil pengisian kuesioner, maka didapatkan data sebagaiberikut.

Tabel 14. Hasil Penilaian System Usability Scale

\begin{tabular}{llllll} 
No & Responden & Total & Acceptibility & Grade & Adjective \\
& & Score & Range & Scale & Ratings \\
\hline $\mathbf{1}$ & PPKA1 & 55 & Marginal & F & Good \\
\hline $\mathbf{2}$ & PPKA2 & 77,5 & Acceptable & C & Good \\
\hline $\mathbf{3}$ & PPKA3 & 87,5 & Acceptable & B & Best \\
\hline $\mathbf{4}$ & PPKA4 & 67,5 & Marginal & Imaginable \\
\hline $\mathbf{5}$ & PPKA5 & 85 & Acceptable & B & Gxcellent \\
\hline $\mathbf{6}$ & PPKA6 & 62,5 & Marginal & D & Good \\
\hline $\mathbf{7}$ & PPKA7 & 87,5 & Acceptable & B & Best \\
\hline $\mathbf{8}$ & PPKA8 & 85 & Acceptable & B & Best \\
\hline $\mathbf{9}$ & PPKA9 & 80 & Acceptable & B & Best \\
\hline $\mathbf{1 0}$ & PPKA10 & 65 & Marginal & D & Good \\
\hline & & & High & & \\
\hline
\end{tabular}

Berdasarkan Rata-rata nilai SUS Meja Pelayanan Jenis VDU ini memiliki skor 75,25 (Acceptable dan Grade Scale $\mathrm{C}$, dengan kriteria sebanyak 1 responden berada dalam grade $\mathrm{F}$, sebanyak 3 responden berada dalam grade $\mathrm{D}$, sebanyak 1 responden berada dalam grade $\mathrm{C}$, sebanyak 5 responden berada dalam grade $\mathrm{B}$, dan tidak ada responden yang berada dalam grade $\mathrm{A}$

Secara umum, berdasarkan System Usability Scale, meja pelayanan Pengatur Perjalanan Kereta Api Jenis Visual Display Unit ini sudah dapat diterima, namun ada beberapa dimensi yang dinilai oleh sebagian besar responden menjadi titik dimana sistem ini masih dinilai kurang efisien.

\subsubsection{USE Questionnaire}

USE Questionnaire yang digunakan terdiri dari 23 pertanyaan yang dibagi menjadi 4 kategori, kategori pertama adalah Usefulness atau kegunaan, dari 10 responden yang menjawab pertanyaan-pertanyaan ini didapatkan rata-rata nilai dengan skala 7. 
Total nilai untuk komponen Usefulness sebesar 4.98 dengan rincian 4.3 membuat efektif, 4.4 membuat produktif, 5.6 poin meja pelayanan ini bermanfaat, , 5.3 poin untuk pernyataan Meja Pelayanan membuat tujuan yang saya ingin capai lebih mudah diselesaikan 4.9 poin untuk pernyataan Meja Pelayanan ini menghemat waktu ketika saya gunakan, 5.0 poin untuk pernyataan Meja Pelayanan ini sesuai dengan kebutuh an saya, 4.9 poin Meja Pelayanan ini sesuaidengan kebutuhan saya.

Bagian kedua dari USE Questionairre adalah "Ease of Use" atau kemudahan penggunaan dari meja pelayanan jenis VDU ini, total nilai dari kemudahan penggunaan adalah sebesar 5.05 dengan komponen paling rendah yaitu "Saya tidak menemukan inkonsisensi" dan "Saya dapat memperbaiki kesalahan saya dengan mudah" dengan nilai 4,6. Dari penuturan beberapa responden merasa cara pengerjaan tugas berbeda terutama untuk urutan operasi pengerjaan. Adapun pada sistem ini tidak terdapat petunjuk yang menjelaskan cara memperbaiki kesalahan. Namun secara keseluruhan meja pelayanan ini dianggap cukup mudah digunakan.

Bagian ketiga dari USE Questionairre adalah "Ease of Learn" atau kemudahan pembelajaran dari meja pelayanan jenis VDU ini, total nilai dari kemudahan penggunaan adalah sebesar 5.33 dari skala 7 dengan semua komponen memiliki poin di atas 5. Secara keseluruhan meja pelayanan ini sudah cukup mudah untuk dipelajari, hal ini terbukti berdasarkan analis a learnability pada bagian sebelumnya.

Bagian keempat dari USE Questionairre adalah "Satisfaction" atau kepuasan akan meja pelayanan jenis VDU ini, total nilai dari kemudahan penggunaan adalah sebesar 4.66 dari skala 7. Pernyataan "Saya puas dengan meja pelayanan ini" memiliki poin 4.6 , pernyataan "Saya akan

merekomendasikan penggunaan meja pelayanan ini" memilki 4.4 poin, pernyataan "Meja Pelayanan ini menyenangkan saat digunakan" memiliki 4.9 poin, pernyataan "Meja pelayanan ini bekerja sesuai keinginan saya" memiliki 5.0 poin, pernyataan "Meja Pelayanan ini menakjubkan" sebesar 4.1 poin, pernyataan "Saya merasa saya harus menggunakan meja pelayanan ini" sebesar 5,1 poin.

Tabel 15. Rata-rata Skor Tiap Komponen USE Questionnaire

\begin{tabular}{|c|c|c|c|c|}
\hline \multirow{6}{*}{ Responden } & \multicolumn{4}{|c|}{ Component } \\
\hline & \multicolumn{4}{|c|}{ Ease } \\
\hline & & Ease o & & \\
\hline & Usefulness & & of & Satisfacton \\
\hline & & Use & & \\
\hline & \multicolumn{4}{|c|}{ Learn } \\
\hline PPKA 01 & 2,86 & 3,60 & 4,00 & 3,43 \\
\hline PPKA 02 & 5,43 & 5,00 & 5,25 & 5,57 \\
\hline PPKA 03 & 4,86 & 5,40 & 4,50 & 5,57 \\
\hline PPKA 04 & 7,00 & 5,40 & 4,50 & 5,43 \\
\hline PPKA 05 & 5,71 & 6,00 & 6,75 & 4,57 \\
\hline PPKA 06 & 3,86 & 4,00 & 4,75 & 3,29 \\
\hline PPKA 07 & 5,43 & 5,00 & 6,50 & 5,57 \\
\hline PPKA 08 & 5,14 & 6,00 & 6,00 & 4,43 \\
\hline PPKA 09 & 4,43 & 6,00 & 7,00 & 4,86 \\
\hline PPKA 10 & 4,43 & 3,80 & 4,00 & 3,86 \\
\hline Rata-rata & 4,91 & 5,02 & 5,33 & 4,66 \\
\hline
\end{tabular}

Tabel 15 menunjukkan nilai rata-rata keseluruhan untuk masing-masing komponen USE Questionnaire 


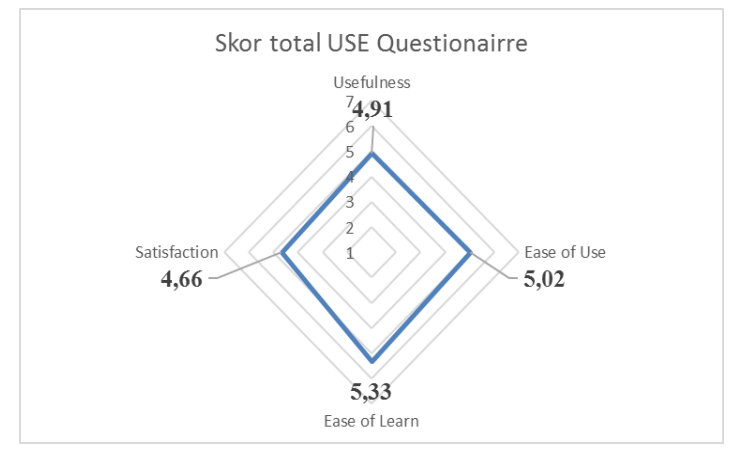

\section{Gambar 5. Grafik Radar USE Questionnaire}

Secara keseluruhan, USE Questionairre ini dapat menggambarkan 4 kriteria yang dijadikan alat evaluasi dari desain interface meja pelayanan pengatur perjalanan kereta api dimana usefulness, ease of use, ease of learn berhubungan dengan effectiveness, efficiency, learnability dan tentunya satisfaction. Hasil pengolahan menunjukkan bahwa komponen usefulness (kegunaan) memiliki poin 4.91, komponen Ease of Use (Kemudahan penggunaan) memiliki poin 5.02, komponen Ease of Learn memiliki poin 5.33 dan komponen satisfaction memiliki poin 4.66 dari skala 7. Dari keempat komponen, komponen yang memiliki penilaian terendah adalah kepuasan (satisfaction) dimana hanya 0.66 di atas poin 4 yang menjadi titik netral, sementara untuk komponen lain berada di rentang 5 dari poin 7 .

Secara keseluruhan berdasarkan kuesioner USE, meja pelayanan ini sudah cukup baik namun belum sempurna, terutama untuk komponen kepuasan. Responden berpendapat bahwa meja pelayanan jenis VDU ini belum terlalu memiliki keunggulan yang benar-benar menonjol dibandingkan meja pelayanan yang biasa mereka gunakan. Fungsifungsi yang ada dalam meja pelayanan jenis VDU ini pada dasarnya sama. Namun dari sisi kegunaan, kemudahan penggunaan maupun kemudahan pembelajaran, sesungguhnya meja pelayanan ini sudah cukup baik.

\subsection{Analisis Retrospective Think Aloud}

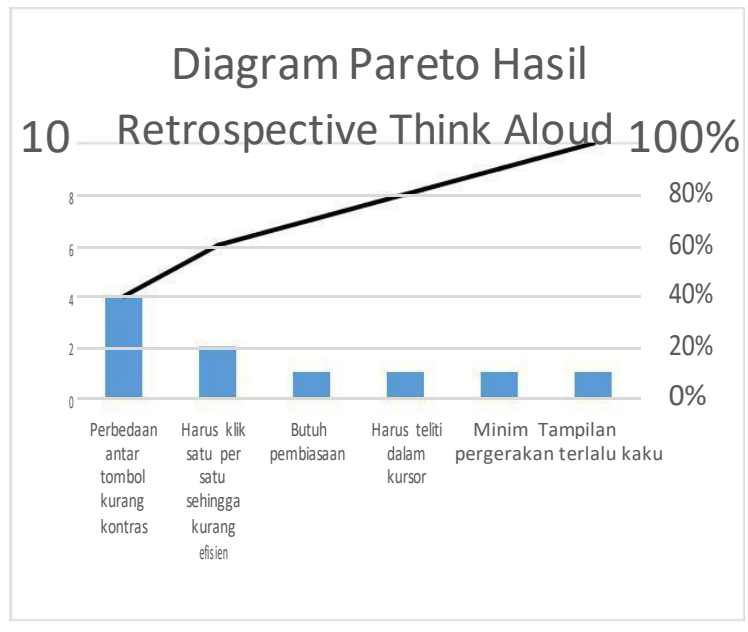

\section{Gambar 6. Diagram Pareto Hasil Retrospective Think Aloud}

Terdapat 2 responden yang menganggap meja pelayanan ini kurang efisien, sebab untuk membentuk rute dibutuhkan mengklik tombol asal dan tombol tujuan satu per satu. Responden menganggap hal ini tidak lebih baik dibandingkan dengan meja pelayanan jenis LCP yang cukup menekan tombol sinyal asal dan tombol sinyal tujuan dalam waktu yang bersamaan, yang mana lebih membutuhkan waktu yang singkat dibandingkan meja pelayanan jenis VDU. 
Kemudian ada responden yang beranggapan untuk mengoperasikan meja pelayanan ini membutuhkan ketelitian, sebab tombol-tombolnya berukuran kecil sehingga terkadang responden tidak berhasil mengklik tombol tersebut, responden berpendapat seharusnya tombolberukuran lebih besaragar tidak membuat pengguna merasa terganggu.

Ada beberapa hasil retrospective think aloud yang serupa dengan permasalahan solusiyang telah dikemukakan pada analisis sebelumnya. Hasil dari retrospective think aloud ini ditambah dengan hasil dari analisis -analisis sebelumnya dapat digunakan sebagai saran untuk pengembangan desain interface meja pelayanan pengatur perjalanan kereta api.

\section{Kesimpulan}

Tujuan yang ingin dicapai dalam penelitian ini adalah mengevaluasi desain interface meja pelayanan visual display unit berdasarkan standar ergonomi untuk meningkatkan kepuasan petugas PPKA terhadap sistem pengendali perjalanan kereta api

Berdasarkan penelitian yang telah dilakukan maka kesimpulan yang didapatkan adalah sebagaiberikut:

1. Berdasarkan Hierarchical Task Analysis, analis is kesalahan dan metode SHERPA, kesalahan yang paling banyak terjadi adalah kesalahan urutan tugas, kesalahan identifikasi tombol, dan kesalahan penggunaan tombol yang tepat.

2. Berdasarkan dua ukuran efektivitas yang dilakukan, Meja Pelayanan ini sudah sangat efisien dari tingkat keberhasilan pengerjaannya, namun kesalahan-kesalahan masih sering terjadi pada saat pengoperasian meja pelayanan ini saat pertama kali.

3. Berdasarkan dua ukuran efisiensi yang dilakukan, waktu pengerjaan adalah sebesar 3,92 sub Task yang berhasil dikerjakan tiap menitnya. Hal ini sudah cukup efisien mengingat pada kondisi pelayanan kereta yang sesungguhnya, frekuensi kereta datang lebih dari 1 menit sekali. Sedangkan dari segi langkah pengerjaan, meja pelayanan ini membutuhkan 2,6 klik per sub Task, yang mana pada jenis meja pelayanan LCP, semua Task dapat dilaksanakan dalam 1 langkah.

4. Berdasarkan tiga ukuran learnability, meja pelayanan jenis VDU ini sudah mudah dipelajari, hal ini dapat dibuktikan dengan perbedaan signifikan antara percobaan pertama dan percobaan kedua menggunakan paired t-test untuk jumlah error, waktu penyelesaian tugas, dan juga mouse click.

5. Berdasarkan tiga ukuran kepuasan, tingkat kesulitan keseluruhan berdasarkan Single Ease Question adalah 2,27. Berdasarkan Rata-rata nilai SUS Meja Pelayanan Jenis VDU ini memiliki skor 75,25 (Acceptable dan Grade Scale C). Berdasarkan USE Questionnaire, meja pelayanan ini memiliki poin Usefulness, Ease of Use, Ease of Learn, maupun Satisfaction di atas 4.

6. Berdasarkan retrospective think aloud, permasalahan yang paling banyak dikeluhkan oleh responden adalah kurangnya perbedaan tombol yang kontras.

\section{Saran}

Adapun saran yang dapat diberikan yang berkaitan dengan penelitian ini adalah sebagaiberikut:

1. Penelitian ini terbatas pada simulasi untuk satu jenis emplasemen stasiun, pada penelitian selanjutnya, dapat dilakukan analisa performa dengan emplasemen yang berbeda-beda.

2. Penelitian tentang desain interface, atau lebih umumnya interaksi manusia dan komputer, terutama untuk peralatan yang menunjang pekerjaan sehari-hari seperti meja pelayanan pengatur perjalanan kereta api perlu untuk terus dikembangkan. Sebab frekuensi interaksi manusia dengan sistem tersebut sangat tinggi dan memiliki pengaruh terhadap aktivitas kesaharian manusia.

\section{Daftar Pustaka}

Bangour, A., Kortum, P., \& Miller, J. (2009). Determining What Individual SUS Score Mean: Adding an Adjective Rating Scale. Journal of Usability Studies, 114-123.

Lund, A. (2001). Measuring Usability with the USE Questionairre. STC Usability, SIG Newsletter, 8:2.

McCormick, E. J., \& Sanders, M. S. (1993). Human Factors in Engineering and Design. New York: McGraw-Hill.

Newell, A., \& Card, S. K. (1985). The Prospects for Psychological Science in Human Computer Interaction. Human Computer Interaction, 209-242.

PT KAI (Persero). (2014). Annual Report Tahun 2014. Bandung: PT KAI (Persero). 
Nurtjahyo, dkk / Evaluasi Usabilitas Desain Interface Meja Pelayanan Pengatur Perjalanan Kereta Api Jenis Visual Display Unit (VDU)/ Vol. 2, No. 1, Maret 2017 pp 1.-18

PT Kereta Api Indonesia (Persero). (2015). Annual Report 2014. Bandung: PT Kereta Api Indonesia (Persero). Pylyshyn,Z. (1989). The Role of Location Indexes in Spatial Perception: A Sketch of the FINST Spatial-Index Model. A Model of Spatial Indexing.

Sauro, J., \& Lewis, J. R. (2012). Quantifying The User Experience. Waltham: Elsevier Inc.

Simon, H. A., \& Kaplan, C. A. (1989). Foundations of Cognitive Science. Cambridge: Foundation of Cognitive Science, MIT Press.

Stanton, N. A. (2002). Error by Design: Methods for Predicting Device Usability. Design Studies.

Tullis, T., \& Albert, B. (2013). Measuring the user experience. Waltham: Elsevier Inc.

Zaphiris, P., \& Kurniawan, S. (2007). Usability Evaluation, chapter 1-. Human Computer Interaction Research in Web Desing and Evaluation. 